Section Editor

Mitchell S.V. Elkind, MD, MS

Brendon P. Boot, MBBS Jason H.M. Macdonald, FRCR

Geoffrey D. Parker, FRANZCR

Stacey Jankelowitz, PhD

Address correspondence and reprint requests to Dr. Stacey Jankelowitz, Central Clinical School, University of Sydney, and Department of Neurology, Royal Prince Alfred Hospital, Camperdown, NSW 2050, Australia stacey.jankelowitz@sydney.edu.au

\title{
Teaching NeuroImages: \\ Traumatic vertebral arteriovenous fistula
}

\section{Figure $1 \quad$ MRI fluid attenuation inversion recovery images}

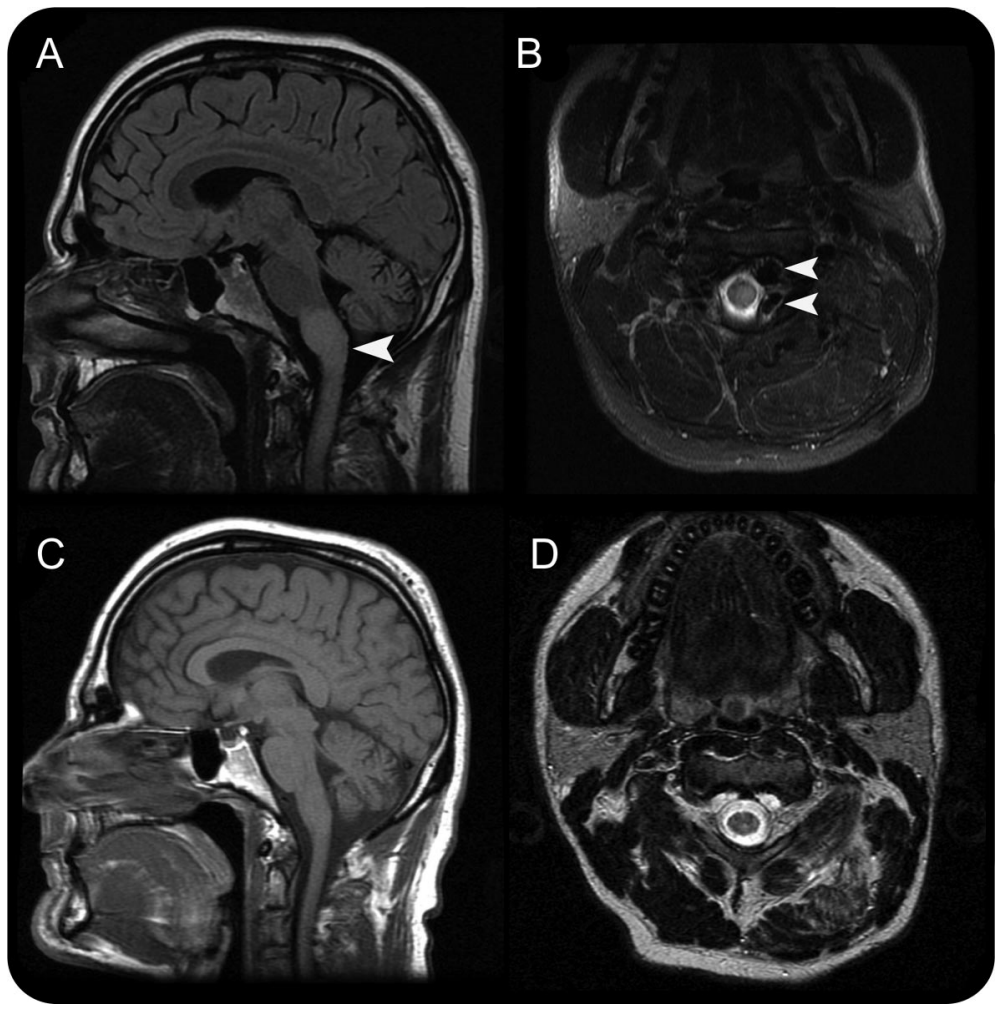

There is swelling and hyperintensity of the medulla and cervical cord $(A)$ and engorged left cervical epidural veins ( $B$, white arrowheads). Six weeks after endovascular occlusion of the fistula, the findings had resolved (C, D).

A 36-year-old man was stabbed in the neck. His left occipital artery was repaired. Ten years later, he noticed a left ear bruit and experienced intermittent paresthesias in the left trigeminal and C5 distributions and bilaterally below the knees. He had a 3-day episode of generalized incoordination. Examination revealed a pulsatile mass and loud bruit below the left occiput with mild weakness and decreased reflexes in the left arm.

MRI (figure 1) and angiography (figure 2) revealed brainstem and cervical cord hyperintensity due to a high-flow vertebrovertebral arteriovenous fistula. ${ }^{1}$ His symptoms and MRI changes probably reflected venous hypertension: 6 weeks after endovascular occlusion they had resolved, and there was no fistula recurrence on repeat angiography. ${ }^{2}$

\section{REFERENCES}

1. Nagashima C, Iwasaki T, Kawanuma S, et al. Traumatic arteriovenous fistula of the vertebral artery with spinal cord symptoms. J Neurosurg 1977; 46:681-687.

2. Herrera DA, Vargas SA, Dublin AB. Endovascular treatment of traumatic injuries of the vertebral artery. AJNR Am J Neuroradiol 2008;29:15851589.

From the Department of Neurology (B.P.B.), Mayo Clinic, Rochester, MN; and Departments of Radiology (J.H.M.M., G.D.P.) and Neurology (S.J.), Royal Prince Alfred Hospital, Sydney, Australia. 
Figure 2 Angiograms of a high-flow left vertebrovertebral arteriovenous fistula

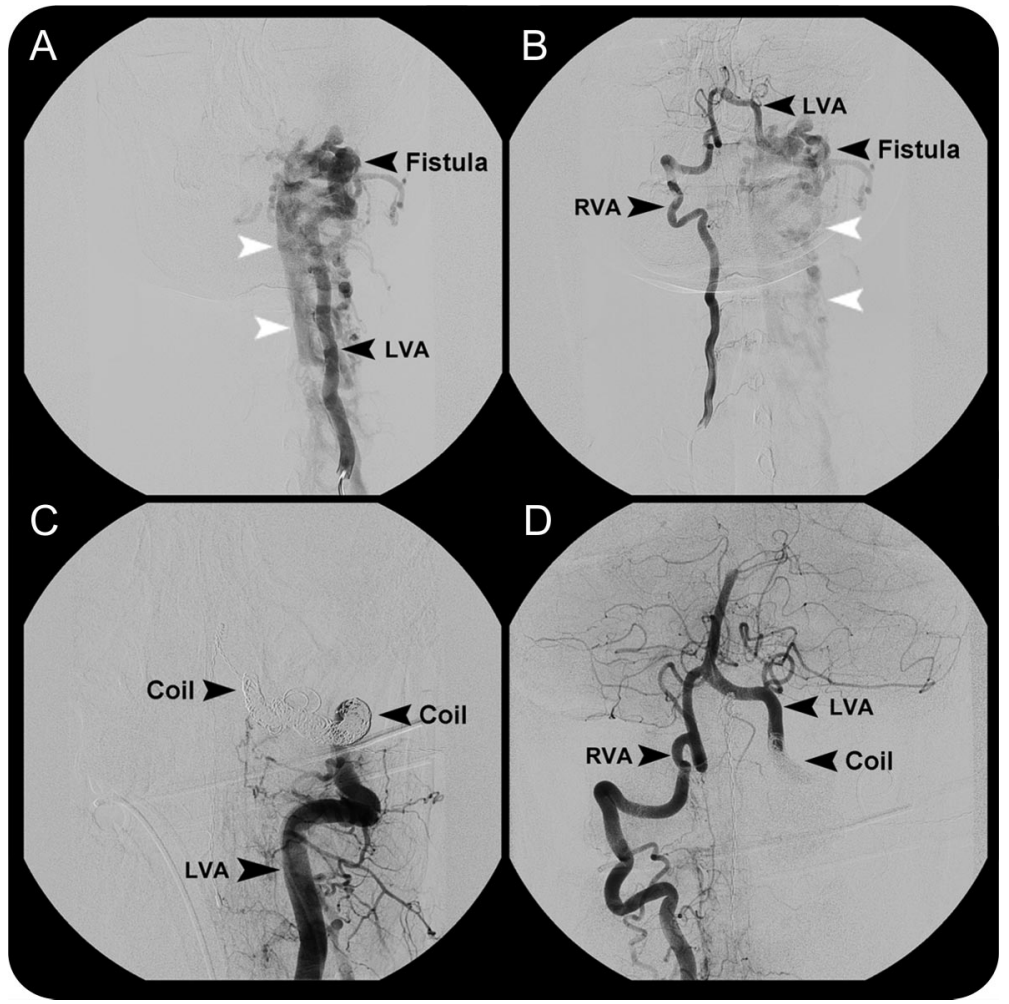

The fistula draining veins (A, B, white arrowheads) drew all flow from the left vertebral artery (LVA) (A). Most of the right vertebral artery flow (RVA) $(B)$ and significant bilateral carotid flow (not shown) also drained to the fistula via retrograde flow in the distal LVA. There was resolution after endovascular occlusion (Coil) (C, D). 


\title{
Neurology
}

\author{
Teaching NeuroImages: Traumatic vertebral arteriovenous fistula \\ Brendon P. Boot, Jason H.M. Macdonald, Geoffrey D. Parker, et al. \\ Neurology 2011;76; $29-\mathrm{e} 30$ \\ DOI 10.1212/WNL.0b013e31820c2eaa
}

This information is current as of February 14, 2011

Updated Information \&

Services

References

Subspecialty Collections

Permissions \& Licensing

Reprints including high resolution figures, can be found at:

http://n.neurology.org/content/76/7/e29.full

This article cites 2 articles, 1 of which you can access for free at: http://n.neurology.org/content/76/7/e29.full\#ref-list-1

This article, along with others on similar topics, appears in the following collection(s):

All Trauma

http://n.neurology.org/cgi/collection/all_trauma

Arteriovenous malformation

http://n.neurology.org/cgi/collection/arteriovenous_malformation

MRI

http://n.neurology.org/cgi/collection/mri

Other cerebrovascular disease/ Stroke

http://n.neurology.org/cgi/collection/other_cerebrovascular_disease_st roke

Information about reproducing this article in parts (figures,tables) or in its entirety can be found online at:

http://www.neurology.org/about/about_the_journal\#permissions

Information about ordering reprints can be found online:

http://n.neurology.org/subscribers/advertise

Neurology ${ }^{\circledR}$ is the official journal of the American Academy of Neurology. Published continuously since 1951, it is now a weekly with 48 issues per year. Copyright Copyright (? 2011 by AAN Enterprises, Inc.. All rights reserved. Print ISSN: 0028-3878. Online ISSN: 1526-632X.

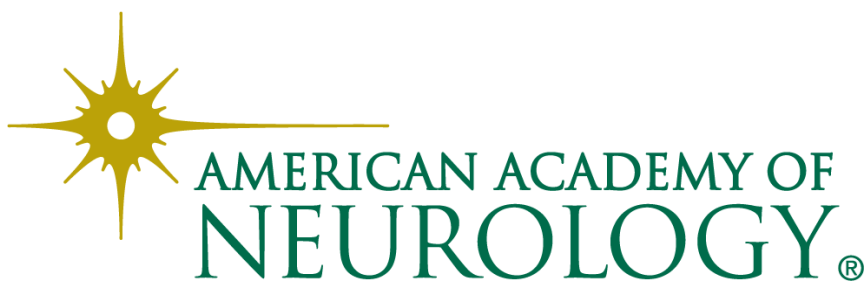

